\title{
Existem grupos sociais nas terras altas da Nova Guiné? ${ }^{1}$
}

\author{
RoY WAGNER \\ tradução: IRACEMA DULLEY \\ revisão técnica: ARIEL Rolim E OlIVIA JANEQUINE
}

O estudo dos arranjos sociais do homem - suas relaçóes com seus pares e como ele as concebe - pertence, tradicionalmente, ao domínio da antropologia cultural. Isso não quer dizer que as relaçóes sociais e o que as pessoas pensam sobre elas não sejam importantes para a arqueologia ou para a antropologia física. Significa, simplesmente, que a sociedade e as relaçôes sociais - e não a constituição física do homem ou o registro de seu desenvolvimento ao longo do tempo - fazem parte do objeto básico da antropologia cultural.

A antropologia cultural é definida de forma quase tão ampla e vaga como o é a antropologia em geral. Uma vez que a antropologia cultural pode incluir estudos a respeito de qualquer coisa, de poesia a aragem do solo, e de fato o faz, os antropólogos frequentemente demarcaram o estudo dos arranjos sociais como antropologia social, um subcampo particular da antropologia cultural. Essa designação tende a ser enganosa, pois sugere que a diferença entre a antropologia social e os outros aspectos da antropologia cultural é principalmente de objeto. Na verdade não é este o caso. A antropologia social tradicional se baseia em algumas suposiçóes muito especiais sobre a importância da sociedade - suposiçôes estas que não são necessariamente partilhadas por outros antropólogos culturais - e inclui um amplo corpus teórico desenvolvido com base nessas suposições. Que suposiçôes são essas e se estamos corretos em separar o estudo da sociedade do restante da antropologia cultural é o tema deste capítulo. Para respondê-lo, entretanto, teremos de deixar esse domínio ambíguo e confuso das definições e examinar o desenvolvimento histórico dos conceitos envolvidos. Afinal, a única justificativa para reconhecer um tipo particular de antropologia é o fato de existir um corpus teórico que nos permite praticar esse tipo de antropologia.

De modo a obtermos um conhecimento mais completo da antropologia social, devemos primeiramente tentar responder a algumas questôes básicas: qual é o fundamento lógico da antropologia social, a antropologia da sociedade? De onde vieram suas suposiçôes e as questôes e respostas referentes a elas?

\section{O desenvolvimento da antropologia social}

Em muitos aspectos, os supostos da antropologia social são legado de Émile Durkheim, o brilhante pensador social francês do final do século XIX e início do século XX. Durkheim voltou-se para a vida moral e coletiva do homem - as forças e influências que mantêm os seres humanos juntos, sua "grupidade" em todos os aspectos - como um fenômeno a ser investigado cientificamente. Suas obras enfatizaram com tanta exclusividade a importância básica do 
"social", dos aspectos coletivos e morais da vida humana, que é fácil usá-los como fundamento para o determinismo social ou acusar Durkheim de "reificar" a sociedade - transformá-la em "coisa". Suas conquistas serviram de base para uma ciência da integração social cujo foco é a maneira pela qual as associaçóes humanas e a própria sociedade, a mais "permanente" das associações, se unem e o que as mantém juntas. Essa preocupação com a "integração" foi a rocha sobre a qual a antropologia social se erigiu.

$\mathrm{Na}$ esteira de Durkheim, o "problema" da sociedade foi assumido e desenvolvido por duas tradiçôes nacionais distintas. Na França, em torno do periódico L'Année Sociologique, os colaboradores e alunos de Durkheim criaram um seminário teórico. Muito desse trabalho, especialmente o do sobrinho de Durkheim, Marcel Mauss, preparou o terreno para o posterior estruturalismo de Lévi-Strauss. Mas foi na Inglaterra - e onde quer que a influência de A. R. Radcliffe-Brown se tenha feito sentir no exterior - que a teoria da descendência teve seus primeiros e mais expressivos sucessos.

Esses sucessos foram genericamente chamados de funcionalismo (embora o próprio Radcliffe-Brown tenha evitado esse rótulo), e ele forneceu o núcleo teórico para a antropologia social clássica que se desenvolveu na Inglaterra nas décadas de 1930, 1940 e 1950. O funcionalismo se assentava na noção de que não importa o quão estranhas ou peculiares fossem as práticas e "instituiçóes" de um povo, e a despeito de como vieram a ser dessa forma, a questáo importante era como funcionavam. Ademais, embora houvesse inúmeras maneiras pelas quais elas pudessem funcionar ou não, havia sempre uma função mais ou menos central, a de manter a sociedade unida - e os antropólogos sociais sempre insistiram que se tratava de uma questâo "política" ou "político-jural".

A suposição "político-jural" foi a contribuição de uma tendência britânica de pensamento muito secular e pragmática ao problema original de Durkheim. E foi Radcliffe-Brown quem escolheu o domínio da jurisprudência - com suas distinções refinadas e suas esmeradas adjudicaçóes de "direitos" - como modelo para pensar as coletividades morais da sociedade. É claro que as sociedades tribais do tipo estudado por Radcliffe-Brown, Evans-Pritchard, Fortes, Gluckman e outros antropólogos sociais não tinham política no sentido que atribuímos ao termo, nem tampouco tinham leis, embora muitas delas possuíssem tribunais e entrassem em litígios. Ademais, a ênfase nos "direitos" levou naturalmente a uma consideração dos direitos de herança e a uma preocupação com a "propriedade", embora a propriedade em questáo fosse, na maior parte dos casos, valorizada precisamente porque era passível de ser trocada por pessoas, o que quase nunca ocorre com a propriedade em nossa sociedade.

A antropologia social evoluiu gradativamente para uma espécie de jogo de fingimento heurístico: conceitos com ampla base de aceitação e compreensão na sociedade ocidental - tais como "política", "lei", "direitos" e "propriedade" - foram aplicados aos usos coletivos dos povos tribais com uma espécie de "como se" implícito. Contanto que os participantes do jogo mantivessem o "como se" em mente, seu uso dos conceitos ocidentais para traduzir os costumes nativos para o tipo de coerência racional e legal que esperamos de nossas próprias instituiçóes era aceito, ainda que ele colocasse os sujeitos nativos nos improváveis papéis de advogados e juízes de peruca e transformasse sua existência coletiva em uma cômica paródia do Banco da Inglaterra.

No entanto, o jogo não poderia acontecer no vácuo. Tratava-se antes de mais nada de antropologia descritiva, e era necessário avir-se com os costumes do povo descrito. Ora, é disso que tratam todos os problemas e conceitos da antropologia social. Se os Bantu meridionais, 
os Nuer ou os Talensi não tinham leis propriamente ditas, entáo usos coletivos análogos teriam de ser encontrados para substituí-las. $\mathrm{Na}$ verdade, estabeleciam-se analogias com as regularidades (ou, como uma geração posterior as chamaria, "normas") que regem as relaçóes de parentesco, e o jogo se tornava um jogo de transformar o parentesco em jurisprudência e economia corporativa - o estudo dos "sistemas de descendência" e das "instituiçôes" formadas nas sociedades tribais pela descendência dos direitos e da propriedade. A antropologia social tornou-se a ciência dos grupos de descendência, e os grupos de descendência e sua constituição tornaram-se questóes cruciais para dar conta da função nuclear de integraçáo e manutençáo da coesão da sociedade. Quanto maior a ênfase com que os pesquisadores insistiam na importância das definiçôes, da racionalidade e de suas próprias concepçóes de direito e propriedade, mais os grupos se tornavam substanciais e claramente definidos. Eles se tornavam, em resumo, muito mais parecidos com os grupos conscientemente organizados, planejados e estruturados da sociedade ocidental - a despeito da completa falta de evidências de que os nativos realmente os pensassem daquele modo. Os "grupos" eram uma funçáo do nosso entendimento do que as pessoas estavam fazendo, e não do que elas mesmas faziam das coisas.

A ciência dos grupos de descendência submeteu-se ao mais rigoroso teste ao lidar com os modos como os usos nativos não correspondiam a suas expectativas teóricas. Havia casos em que o uso do parentesco contradizia patentemente as expectativas do modelo institucional da sociedade. Nas sociedades tribais que a antropologia social escolheu como objeto de estudo, casos como esses não eram nem incomuns, nem triviais. O refinamento da chamada "teoria da descendência” foi realizado por meio do esforço contínuo para lidar com contradiçóes desse tipo. $\mathrm{O}$ início disto fica evidente nos arti- gos clássicos de Radcliffe-Brown, reeditados em Estrutura e função na sociedade primitiva. Eles tratam do direito de um jovem bantu meridional de "furtar" comida e bens que pertencem a seu tio materno, geralmente membro de outro grupo de descendência, e das peculiares relaçóes de "jocosidade" e "evitação" encontradas entre muitos povos tribais, nas quais os participantes se envolvem numa troça que parece violar a relação ou na evitação que aparentemente a nega. Radcliffe-Brown escolheu interpretar todos esses fenômenos em termos do que chamou de "aliança ou associação". Em vista das tensôes resultantes de interesses divergentes dos diferentes grupos que casavam entre si, inclusive demandas conflitantes a respeito de uma única pessoa ou de expectativas desta, essas práticas inexplicavelmente "antagônicas" serviam para manter a ordem e a solidariedade social ("integrar a sociedade”) quando nada mais podia fazê-lo. Nas palavras de Radcliffe-Brown:

A aliança pelo respeito extremo, pela evitação parcial ou completa, evita esse conflito mas conserva as partes unidas. A aliança pela jocosida$\mathrm{de}^{2}$ faz a mesma coisa, mas de modo diferente. (1973, p. 131)

O caráter aparentemente anti-social do "furto" ou das relaçóes de jocosidade e evitação poderia, assim, ser explicado pela necessidade de integrar os próprios grupos (aliá-los) em um todo social mais amplo. Qualquer evidência no sentido de que o uso do parentesco náo tinha o efeito de promover a solidariedade entre os grupos poderia ser explicada como formadora da solidariedade como um todo através da aliança.

A ciência dos grupos de descendência se defendia contra as exceçôes etnográficas partindo do princípio de que a própria sociedade era, ela mesma, apenas um grupo de descendência maior e melhor, com suas próprias leis e modos de operação. Não era preciso deixar de acreditar 
em grupos sociais ou em solidariedade; bastava admitir que a solidariedade às vezes era alcançada por meios indiretos. Foi esta engenhosa formulaçáo de Radcliffe-Brown, que salvava a solidariedade do grupo das garras da irracionalidade frívola, que Meyer Fortes usou como fundamento para sua teoria da descendência e da filiaçáo. Para começar, se a "descendência" que os antropólogos vinham usando como um tipo de fundamento legal para a constituição de grupos não era o único princípio em operação, então um princípio mais geral teria de ser encontrado. Este foi a "filiação", um tipo de descendência de mão dupla baseada nos vínculos de um indivíduo tanto com o pai quanto com a mãe. A descendência, realizada por meio da mãe ou do pai, correspondia ao que Fortes chamava de forma de filiação "com maior peso social", ao passo que o outro tipo, que relacionava um indivíduo às pessoas que estavam fora de seu grupo de descendência, era denominado "filiação complementar". A primeira fornecia aos grupos um fundamento jurídico ou "político-jural", ao passo que a segunda proporcionava um meio para a aliança entre os grupos (embora fosse suplementada por elementos como o ritual).

À primeira vista, essa manobra estratégica de Fortes parece ter resolvido o dilema do antropólogo social de, ao mesmo tempo, dispor dos grupos de descendência como "instituições" claramente delimitadas e, ao mesmo tempo, admitir os interesses da totalidade social mais ampla. Contudo, essa solução custou alguma contradição interna, pois a filiação tomava com uma máo o que oferecia com a outra. Ela afastou o centro de gravidade teórica do franco racionalismo de Durkheim e Radcliffe-Brown de tal forma que quando os teóricos da descendência mais recentes, como Goody, quiseram estabelecer uma definição para grupo de descendência "corporado", foram obrigados a inventar conceitos como "reivindicações obscuras" e "direitos submersos" para explicar o funcionamento da filiação complementar. Estes se referem às frágeis reivindicaçóes de propriedade ou direitos que um homem pode exercer no grupo de nascimento de sua mãe em virtude do fato de que "sua mãe poderia ter sido um homem". Se sua mãe fosse um homem, ele estaria no grupo dela devido à herança patrilinear de "direitos" (de ser membro desse grupo). Se as reivindicações fossem claras, em vez de obscuras, e os direitos viessem à tona, então as fronteiras dos grupos corporados de descendência, que eram estabelecidas exatamente por esse tipo de direitos e reivindicaçôes, seriam corroídas e comprometidas. E, se isso acontecesse, os antropólogos sociais teriam de admitir que os grupos, tal como eles os haviam concebido, não existiam.

As reivindicações obscuras e os direitos submersos eram simplesmente uma forma de dizer que as relações (de "aliança ou associação") entre os grupos simplesmente não eram tão "reais" quanto os próprios grupos. Esse status obscuro peculiar era reservado para tudo o que realizava a mediação entre as fronteiras rígidas dos grupos e se movia em seus interstícios - inclusive o "ritual" (religião). (Todos sabiam que o ritual lidava com coisas sobrenaturais e sem substancialidade, como pessoas, gado e terras de família.) Assim, os antropólogos sociais tendiam a tornar seus grupos sólidos e substanciais sacrificando a realidade e a substancialidade de tudo o mais.

Mas o mundo obscuro e sem substancialidade dos direitos e reivindicaçóes que se moviam de forma inexplicável entre os grupos ainda colocava um grande desafio à ciência dos grupos de descendência. O próprio caráter intersticial e não substancial desse mundo era provocador; assim, muito esforço teórico foi dedicado a derivar algum tipo de justificativa da realidade do náo substancial, o que, é claro, tornou-o mais necessário, mais provocador $\mathrm{e}$ 
mais importante. A solidariedade passou a ser explicada por meio do antagonismo, em vez de ser definida em contraposição a ele, e a sociedade acabou por ser entendida nos termos de uma anti-sociedade.

A teoria dos "rituais de rebelião" de Gluckman, que se refletia em muitos aspectos da vida social africana, representou mais um passo nessa direção. Gluckman insistia em que a dramatização pública institucionalizada de uma rebelião jocosa contra o governante, realizada com regularidade em algumas sociedades africanas, servia para reforçar a posição desse governante. Ao estabelecer um tipo de "falsa negação" da autoridade dele, uma espécie de relação de jocosidade política coletiva, e então superar a negação, a ordem social se convertia no que era ao fracassar em se converter no seu oposto. A importância dessa teoria reside em seu emprego da contradição como base para a explicação. Embora firmemente comprometida com a integração funcional da sociedade, ela assinala um deslocamento radical no centro teórico da antropologia social.

Com isso, abriu-se o caminho para uma antropologia social voltada em grande medida para o domínio do ritual e do "nem lá, nem cá”3. Foi este o rumo tomado por dois antropólogos sociais modernos: Mary Douglas e Victor Turner. Em seu livro Pureza e perigo, Douglas ressaltou a posiçáo central das situaçóes contraditórias ou paradoxais na sociedade humana e relacionou-as à noção de poluição. Turner, na esteira de Gluckman, concentrou-se no processo ritual e na importância da transição (liminaridade) entre estados sociais e rituais. Embora o social conserve sua proeminência na obra de ambos, o crescente apoio dos autores no contraditório remete a outra divergência importante: em lugar da integração funcional, suas explicaçóes recorrem cada vez mais ao significado e à conceitualização como expressos nos símbolos.
Se essa ênfase na contradição e no "nem lá, nem cá” reduziu a ciência dos grupos de descendência a uma espécie de absurdo em relação a sua posição anterior, o interesse pelos símbolos e pela conceitualização nativa teve um efeito semelhante sobre o jogo heurístico de compreender os usos nativos como se fossem instituiçóes ocidentais. Podemos concluir que a antropologia social foi instigada a se converter no seu oposto pelas exigências de lidar com seu objeto de estudo. Mas a essa altura seu oposto (no que diz respeito a suas principais ênfases) já havia surgido na forma do "estruturalismo" lévi-straussiano e havia entabulado um debate contínuo e bastante bem-sucedido com a teoria da descendência, sob a orientação de Edmund Leach e Rodney Needham.

O estruturalismo de Claude Lévi-Strauss é o "oposto" da antropologia social tradicional radcliffe-browniana: voltou-se para as oposiçôes e contradições no interior da ordem social - com o propósito de resolvê-las como parte de sua explicação -, e não para suas regularidades legais e harmonias integradas. A obra de Lévi-Strauss emergiu de uma tradição diferente de antropologia, fundada pelos alunos e seguidores de Durkheim na França, que haviam desenvolvido um corpus teórico sobre a sociedade em conformidade com as linhas conceitualistas da obra do próprio Durkheim, e não com a orientação legalista e materialista da antropologia social britânica. Eles escreveram sobre os temas da "classificação primitiva", da organização dualista, dos conceitos de eu e sociedade e das formas de troca de dádivas. Talvez a mais conhecida dessas obras seja o brilhante Ensaio sobre a dádiva de Marcel Mauss, livro que, como o próprio Mauss, exerceu grande influência sobre Lévi-Strauss.

É na troca de dádivas, ou reciprocidade, que o estruturalismo começa. Ou, antes, é onde o funcionalismo acaba para os estruturalistas, pois a reciprocidade entre indivídu- 
os e entre grupos é a resposta estruturalista à questão funcionalista: "O que integra a sociedade?". Ao supor a presença e importância universal da reciprocidade, o estruturalismo elegeu como principal problema a maneira como a sociedade e suas partes são conceitualizadas. Assim, reverteu completamente a orientação do funcionalismo, que considerava esse tipo de conceitualização como um dado e voltava sua atenção para o problema da integração.

A partir de Estruturas elementares do parentesco (Les Structures Elementaires de la Parenté) de Lévi-Strauss, publicado em 1949, o grupo social assumiu um aspecto novo e radicalmente diferente para alguns antropólogos. Foi descrito em termos conceituais ("ideais") e simbólicos, e não legais e materialistas. Ao invés de se basearem em vacas, complexos residenciais e direitos in rem e in personem, os grupos e a estrutura dos grupos se baseavam em dualidades cosmológicas: direita versus esquerda, água em contraposição a terra, o de cima em oposição ao de baixo, etc. Em vez de grupos reais, físicos, "concretos", havia unidades hipotéticas reconstruídas de acordo com os papéis assumidos na reciprocidade - "doadores de mulheres", "receptores de mulheres", "ciclos" determinados por regras de casamento, e assim por diante constructos sociais do analista concebidos para fazer operar a ideologia nativa.

Uma vez que se pretendia que esses constructos replicassem algo do "espírito" do nativo, em vez de algo a respeito do qual o pesquisador de campo pudesse esboçar um mapa, como um complexo residencial, seria inexato chamá-los de "grupos" no mesmo sentido dos constructos da antropologia social. Ainda assim, a despeito desse acréscimo de sofisticação, os constructos não eram, em muitos aspectos, menos "grupais" do que os grupos de descendência da antropologia britânica. A principal diferença era que esses grupos de descendência existiam na imaginação do nativo, a despeito de sua aparência "concreta". Eram grupos de descendência precisamente pelo mesmo motivo que as unidades básicas de Radcliffe-Brown o eram - porque Lévi-Strauss, como os antropólogos britânicos, considerava as relaçóes de parentesco como lócus da "lei" ou das "regras" nas sociedades tribais.

Ao seu modo, entretanto, ele não começou por regras de herança ou propriedade, mas pelo tabu do incesto, que considerou a regra de casamento arquetípica. É desse tabu, segundo Lévi-Strauss, que descende o "universo de regras" que constitui a sociedade humana. Ora, foi desse tabu, com sua necessidade implícita de reciprocidade ("Já que náo posso casar com minha irmá, trocá-la-ei por alguém com quem possa me casar"), que ele derivou o fundamento da descendência: "O aspecto positivo da proibição é que ela inicia a organização” (Lévi-Strauss, 2003).

A "organização" revelou-se uma incorporação da descendência em todas as suas formas e variedades tradicionais ("patrilinear", "matrilinear", e assim por diante), com a exceção de que era significativa em termos conceituais, e não materiais. E embora esse empréstimo da terminologia tradicional pudesse não ter sido necessário para uma teoria que precisava dos grupos apenas como um tipo de quadro para "ancorar" relaçóes de reciprocidade, o estruturalismo necessitava de algum tipo de ordem e organização, pois partilhava com o funcionalismo a visão de que uma cultura ou sociedade representa uma ordem sistêmica de alguma espécie, um "sistema".

Tanto a antropologia social britânica quanto o estruturalismo lévi-straussiano elegem como tarefa a descoberta de algum tipo de ordem sistêmica no interior da cultura estudada, uma ordem que identificam com a forma como essa cultura "opera" (funcionalismo) ou se articula conceitualmente (estruturalismo). Vimos que a antropologia social tentou primeiramente 
descobrir essa ordem no interior dos próprios dados, postulando a existência de grupos de descendência auto-evidentes e similares, mas gradualmente assumiu a posição de que os problemas básicos eram de cunho conceitual e interpretativo. Em outras palavras, assim como o estruturalismo, passou a reconhecer a importância de construir modelos do "sistema nativo" e averiguá-los como um modo de explicação.

Esse procedimento implica observar algo e entáo descrevê-lo de forma sistêmica, ou arquitetar um sistema e então demonstrar que ele "está lá", ou se parece bastante com o que "está lá”. Na prática, geralmente inclui um pouco de ambos. Em qualquer dos casos, contudo, envolve a invenção e a projeção de uma "ordem" por parte do antropólogo, que é função de seu processo de entendimento. Assim, se escolhermos desafiar esse modo sistêmico de explicação, podemos perguntar se os grupos de descendência e a parafernália da ordem social a eles associada existem de fato independentemente da necessidade do antropólogo de explicar as coisas nesses termos. Existe algo sobre a sociedade tribal que requer sua decomposiçáo em grupos? Ou a noção de "grupos" é uma descrição vaga e inadequada de algo que poderia ser mais bem representado de outra forma?

\section{Desafiando a suposiçáo do "como se"}

Nosso primeiro passo ao tentar responder a essas questóes deve envolver uma avaliação franca do que buscamos. Afinal, se abordarmos a questão com a intençáo explícita de encontrar grupos ou com uma suposição irrefletida de que grupos, de um tipo ou de outro, são essenciais para a vida e a cultura humana, entâo nada nos impedirá de encontrá-los. Ora, se nosso objetivo for uma avaliaçáo franca, devemos ter clareza sobre o que queremos dizer ou esperamos encontrar com grupos. Temos em mente os "grupos corporados" rígidos, empíricos e materiais dos antropólogos sociais, as gradaçóes sociais inclusivas, flexíveis e de base genealógica de um sistema de linhagens segmentares, ou os constructos totalmente conceituais dos estruturalistas? Antes de tudo, deveríamos tentar responder à questáo crucial: por que, afinal, precisamos explicar as estruturas sociais por meio dos grupos?

Vivemos em uma cultura na qual fundar, integrar, tornar-se membro e participar de grupos é uma questão intencional e importante. As constituições de nossas nações baseiam-se em uma noção de "contrato social", um ato ou evento consciente de alguma espécie que deu início à existência da sociedade. Os cidadáos são membros desses colossais "grupos de descendência". Os que não são "nascidos" neles ou no interior dos seus territórios clânicos precisam ser "naturalizados", assim como as crianças podem ser adotadas legalmente por pais de criação. Uma sociedade que enfatiza o dever do cidadáo de votar e manter-se vigilante aos interesses de seu país sem dúvida insiste na participaçáo consciente. E ao tornar consciente a pertença e a participação na sociedade, essa forma social particular também a torna problemática. Os problemas de recrutamento, participação e corporativismo (economia) são nossos problemas, mas nós os levamos conosco quando visitamos outras culturas, junto com nossa escova de dentes e nossos romances favoritos.

Naçóes, sociedades e grupos são a forma ou manifestação social da confiança na ordem, na organização e na coerência que perpassa toda nossa abordagem de um fazer e compreender coletivo como um pressuposto inconteste. A sugestão de que nossas ideias sobre ordem, organização e coerência podem estar abertas a uma revisáo crítica ou, no plano social, de que os grupos podem não ser a questão mais importante, é tomada por muitos como uma traição a nossa ética social e acadêmica. Mas 
tudo que estamos fazendo é desafiar o "como se" da antropologia sistêmica, a atitude dos antropólogos sociais britânicos e dos estruturalistas franceses, que diz: "Vamos supor que os nativos são como nós para que possamos entendê-los". E estamos desafiando essa suposição para evitar uma perspectiva antropológica que inadvertidamente faz com que nossas próprias suposições culturais se tornem parte "da forma como as coisas são", da forma como toda a humanidade pensa e age.

Os antropólogos têm uma responsabilidade ética ao lidar com outros povos e mundos conceituais com base na igualdade e mutualidade. Quando um antropólogo resume a vida e a imaginação de seus sujeitos de pesquisa em um "sistema" determinista que ele mesmo arquiteta, capturando os pendores e inclinaçóes destes no interior das necessidades das economias, ecologias e lógicas próprias ao antropólogo, ele afirma a prioridade do seu modo de criatividade sobre o deles. Substitui a forma como os "nativos" fazem suas coletividades pelo seu próprio fazer ("heurístico") dos grupos, ordens, organizações e lógicas. E é esse modo "nativo" de fazer a sociedade, e não suas curiosas semelhanças com nossas noçóes de grupos, economia ou coerência, que move nosso interesse aqui. $\mathrm{O}$ entendimento dessa criatividade per se é a única alternativa ética $e$ teórica aos esforços paternalistas que "civilizariam" os outros povos ao transformar os remanescentes de seus esforços criativos em grupos, gramáticas, lógicas e economias hipotéticas.

Ao perguntar se existem grupos sociais nas terras altas da Nova Guiné, não estou preocupado com quais tipos de "grupos" melhor descrevem os arranjos comunais locais, mas com a forma como as pessoas se criam socialmente lá. As respostas a essa questão poderão ajudar-nos a dizer se os "modelos" do grupo corporado, do sistema de linhagens segmentares, ou da unidade conceitual "estrutural" têm qualquer relevância particular para aquela situação, e podem nos revelar ainda mais. Temos inúmeras maneiras de definir grupos - com base na residência, genealogia, política, economia, e assim por diante -, assim como temos muitos tipos de definiçóes para grupos - inclusive os mencionados acima e os constructos marginais ou negativos ("grupos" que não são grupos) denominados "parentela", "quase-grupos" e "redes" -, mas praticamente não dispomos de nenhuma alternativa inteiramente satisfatória para o conceito de coletividade grupal. Pior ainda, não contamos com nenhum conjunto de critérios para determinar quando um conceito como este é aplicável e quando náo é.

Como a noção de grupo é nossa, o problema de encontrar critérios como esses cabe a nós. Visto que no âmago de nossa noção (e de nossos motivos para encontrar grupos) encontra-se um foco coletivo deliberado, um sentido de participação e consciência comuns, nossos critérios devem enfatizar esse fator. Outras formas de agrupar as pessoas - com base em suas semelhanças compartilhadas, sejam elas especificidades de residência comum ou contígua, cooperação ou envolvimento econômico ou ecológico, genealogia ou comportamento político - podem facilmente se tornar dispositivos para criar grupos a partir de pessoas que, elas mesmas, nunca o fariam dessa forma (ou, talvez, não o fariam de forma alguma). Um povo possui grupos na medida em que, e segundo a forma como, concebe tais coisas; caso contrário, o antropólogo simplesmente "possui" as pessoas ao impor sua ideia de "grupos" a elas.

Como, entáo, os povos das terras altas da Nova Guiné criam sua socialidade? Quais são os "fatos", tais como os nativos os fazem? Eles têm a "sociedade como problema" e uma solução sistêmica para ela, ou seus problemas são concebidos de forma totalmente diferente, relacionando-se apenas indiretamente ao agrupamento social? Podemos aprender a compre- 
ender ou simular sua criação dos "fatos" sociais sem transformá-los em peôes ${ }^{4}$ do nosso próprio jogo? Uma maneira de tentar responder a essas questóes é considerar um povo específico de tantos pontos de vista quantos forem possíveis, com certa ingenuidade, especialmente no que concerne a grupos e sistemas, da forma como um pesquisador de campo poderia abordá-los. Consideremos dessa maneira os Daribi, povo do leste das terras altas da Nova Guiné entre os quais fiz pesquisa de campo.

\section{A socialidade daribi}

Se pudéssemos voltar no tempo e visitar Baianabo, o local onde vivi durante grande parte de meu primeiro período de campo (19631965), por volta de 1950, dez anos antes de o povo daribi ser "pacificado" pelo governo, lá encontraríamos roçados e um pequeno povoado. Talvez vocês não reconhecessem os roçados como tais, pois eles seriam do tipo "coivara" ou "corte-e-queima", com troncos de árvores mortas e sem folhas ainda eretos ou jazendo onde haviam caído, cobertos pela folhagem de batata-doce (a base da alimentação). Ao redor haveria áreas de "floresta secundária": antigos roçados em vários estágios de recrescimento da floresta, e talvez também clareiras que vão sendo abertas para novos roçados. Ao redor disso tudo, sobre um amplo planalto vulcânico cerca de mil metros acima do mar, encontra-se uma floresta tropical madura, repleta de árvores de tronco branco ou cinza com $1,50 \mathrm{~m}$ a $1,80 \mathrm{~m}$ de diâmetro na base.

Aqui vivem cerca de quatro ou cinco homens adultos com suas famílias. $\mathrm{O}$ mais velho é um homem baixo, com cabelo embranquecendo, de nome Buruhwą 5 . Perguntamos-lhe quem são suas "pessoas de casa" (uma expressão local); ele hesita, murmurando "as pessoas de minha casa", e então diz: "Weriai". Em con- versa com ele, descobrimos que nasceu num local chamado Waramaru. Então sua irmã se casou em Peria, um amplo complexo de casas e roçados cerca de $1,5 \mathrm{~km}$ ao norte de onde estávamos; e ele se mudou para cá, para Baianabo, "para ficar perto dela".

A impressão é de que estávamos nos deparando com uma daquelas situaçóes geralmente conhecidas na antropologia social como um "caso especial", mas na verdade esse tipo de história pessoal é comum entre os Daribi. Perguntamos aos outros homens sobre suas "pessoas de casa" e locais de nascimento e descobrimos que eles são "Weriai" ou "Kurube", nascidos em Waramaru. Onde vivem os outros Weriai? Descobrimos que alguns vivem em uma casa bem próxima, muitos outros vivem em Waramaru, com o "povo de Noru" ou o "povo de Sogo", e muitos outros vivem com um povo chamado "Nekapo". Acabamos por descobrir que Waramaru fica a um bom dia de intensa caminhada a oeste, com muitos outros povos no meio, e que o povo de Nekapo vive a talvez meio dia de caminhada para além desse ponto. Se os Weriai são de fato "pessoas de casa", eles certamente estão espalhados por uma considerável nesga de paisagem; e se alguns vivem com os Peria, outros com os Sogo ou Nekapo, também parecem estar bem distribuídos. É isto um "grupo", uma "tribo", um "clã não localizado"? O que quer que possa ser, o que significa Kurube? Será talvez um outro nome para Weriai? Mas antes de pegarmos nossos exemplares de Notes and Queries in Anthropology, o guia padrão do pesquisador de campo em situaçóes como essa, para buscarmos uma definição adequada, deveríamos nos lembrar de que estamos deliberadamente tentando náo jogar o jogo "heurístico" de chamar socialidades desconhecidas de "grupos" para aliviar nosso senso explicativo. Uma definiçáo padrão, centrada nos grupos, simplesmente não será suficiente, ao menos até que tenhamos aprendido mais sobre essas pessoas. 
246 | Roy WAGNER

Termos gerais como "pessoas de casa" e termos específicos como Weriai, Kurube e Noru fazem parte dos vastos meios sempre em expansão de que os Daribi se valem para estabelecer distinções sociais. Os últimos são chamados bidi wai, "ancestrais homens", e caracteristicamente se baseiam nos nomes de ancestrais genealógicos, embora este nem sempre seja o caso. É quase certo que Sogo, Weriai e Kurube são nomes de ancestrais reais ("Kurube" desenvolveu-se a partir de Kuru, que se diz ser outro nome do homem chamado "Weriai"); Noru e Nekapo provavelmente não o são. Mama' Di’be e Huzhuku Di’be (Di’be "claro" e "escuro", respectivamente) distinguem o povo Di'be, que vive próximo ao rio "claro", dos que vivem no sopé da montanha "escura".

Se estivéssemos absolutamente empenhados em "encontrar" grupos, não haveria problema algum em supor que essas descrições são descrições ou definições de grupos concretos, definidos e empiricamente existentes. $\mathrm{O}$ fato de que alguns deles incluem outros poderia ser tomado como evidência da existência de um "sistema de linhagens segmentares" - diz-se que os Weriai, Daie, Sizi e outros são Para, provenientes de certos filhos de um homem chamado Para, que os Kurube eram Weriai que viviam com os Sogo, que os Noruai eram Weriai que viviam com os Nekapo, e assim por diante. Isso resulta em um arranjo hierárquico de grupos que se tornam progressivamente mais inclusivos com base em cálculo genealógico e padronizados em níveis aos quais correspondem rótulos, de modo que os Para podem ser considerados uma fratria, os Weriai um clã, os Kurube um subclã.

A ordem hierárquica necessária a um modelo desse tipo certamente está lá, implícita no fato de que se pode considerar que os termos se incluem, excluem ou contrastam uns com os outros. Contudo, seria prudente considerar as distinçôes a partir de seu valor nominal, apenas como distinçóes e não como grupos. Elas agrupam as pessoas apenas na medida em que as separam ou distinguem com base em algum critério, e não podemos deduzir das distinçóes conceituais uma correspondência real entre os termos e os grupos de pessoas distintos e conscientemente percebidos.

Os termos são nomes, não são as coisas nomeadas. Eles diferenciam ao dizer: "Estes são os do rio; aqueles são os da montanha", ou "Estes são provenientes de Weriai; aqueles, de Daie", e são significativos não por causa da forma como descrevem algo, mas por causa da forma como o contrastam com os outros. Em sua brilhante análise do "totemismo", Lévi-Strauss conclui que "Não são as semelhanças, mas as diferenças que se assemelham" (1975). Assim, embora Weriai signifique "cegado" em daribi e Daie signifique "estar completamente cozido", nenhum dos dois tem significado literal; trata-se apenas de nomes, e nessa condição o conteúdo de um diferencia de forma táo efetiva quanto o do outro.

Como nomes usados para estabelecer distinções, esses termos são muito flexíveis. "Para", por exemplo, é uma contração de pariga ("caixa torácica") e às vezes é usado como apelido que indica preguiça ("Ele é chamado de 'costelas' porque passa o dia todo deitado sobre elas"). Seja por este motivo ou por algum outro, estabeleceu-se uma associaçáo entre o nome e um homem que teria supostamente originado diversas linhagens de substância paterna, um bidi wai comum. $\mathrm{O}$ nome pode ser usado para distinguir todas essas linhagens de outros complexos como Noru ou Di'be, para distinguir algumas delas de partes da última (em Waramaru, Weriai chamava o povo de Sogo de "Noru"), ou para distinguir algumas das linhagens de Para de outras. Frequentemente se refere como "Para" àqueles que se autodenominam Sizi, Warai, Ogwanoma ou Siabe em contraposição aos Weriai, por exemplo, ou aos Daie, embora os últimos sejam, sob outros aspectos, tão Para quanto eles mesmos. 
Há bons motivos por trás dessas aparentes irregularidades. Por um lado, os Daribi tendem a usar termos os mais amplos e menos específicos possíveis na maioria das situaçôes. Por outro lado, os Sizi, Warai e Ogwanoma ficaram para trás em Boromaru, lar tradicional dos Para, ao passo que as outras linhagens se mudaram para longe. Mas a despeito disso, dificilmente se pode dizer que os Para representam um grupo, pois é impossível, dada a abrangência do uso do termo, determinar qual das aplicaçóes é a "correta". Para é um nome, não um grupo; é uma forma de distinguir, de incluir e excluir; é, pois, meramente um dispositivo para estabelecer fronteiras.

Um dispositivo desse tipo pode ser usado de forma muito flexível, estabelecendo ora esta distinção, ora aquela, sem nunca se vincular a um elemento particular ou a um "domínio" delimitado de definição. Esse uso "amplo" ou "hiperbólico" dos termos pode ser mais bem exemplificado na distinção daribi das cores. Quando se mostra aos Daribi um objeto verde, azul ou marrom escuro, eles o identificam como huzhuku; quando se lhes mostra algo que chamaríamos de vermelho, escarlate, carmesim, ou mesmo marrom claro, eles designam o objeto como mama'; nosso amarelo ou amarelo-esverdeado são sewa' para eles. Contudo, ao falarem do fruto do pandano, cujas variedades váo em geral do escarlate ao rosa antigo, embora uma delas seja amarelo-mostarda, eles se referirão ao primeiro como huzhuku e ao último como $m a m a$ ! . As qualidades contrastantes dos termos (escuro/claro) revelam-se mais significativas nesse contexto do que os valores mais específicos (de "cor").

Quais são os efeitos sociais desse tipo de uso? Estabelecer fronteiras criando contrastes tem o efeito de eliciar ${ }^{6}$ grupos como um tipo de contexto geral para a expressão de alguém, aludindo a eles indiretamente, e não os organizando ou participando deles de forma consciente.
As coisas que nós imaginamos como "grupos" assumem uma qualidade contínua e praticamente invisível, como nossa noção de "tempo", que igualmente tentamos eliciar e impelir por meio das distinções e dos contrastes arbitrários de nossos relógios e calendários ${ }^{7}$.

A eliciação de coletividades sociais por meios indiretos é mais do que um mero dispositivo retórico entre os Daribi; trata-se de um estilo ou modo criativo que perpassa toda a gama de suas atividades. Um homem que tenha sido ofendido, por exemplo, frequentemente se enfurece e grita, dando vazão a sua raiva deliberadamente até o limite - e se ele provocar um oponente para que este lhe responda com fúria, tanto melhor. Ele está tentando eliciar uma resposta coletiva em forma de conciliação, negociadores da paz que farão com que se entendam, apesar da injúria sofrida, em prol do interesse geral (e para pôr fim à terrível algazarra!).

Os nomes simplesmente delineiam um modo de criatividade cujo aspecto mais sério, ao menos em termos nativos, é o da troca de riquezas. Essa troca, por sua vez, deriva de um outro uso do contraste e da distinção para eliciar relaçôes sociais - nesse caso, a distinção e o contraste mais básicos: entre homens e mulheres. Os homens enfatizam sua "masculinidade" em oposiçáo às mulheres, que em troca afirmam sua "feminilidade", cada qual recebendo do outro uma "resposta" e um aspecto complementar de seu todo social. As mulheres são valorizadas por suas habilidades produtivas e reprodutivas, pela capacidade de realizar trabalho feminino e ter filhos, criatividade à qual os homens respondem assumindo o controle sobre ela. $\mathrm{O}$ controle é obtido pela negociação de "trocas" de mulheres (bem como de sua progenitura, seus "produtos") por produtos e implementos da criatividade masculina - os machados usados no roçado, a carne (inclusive porcos), que se acredita aumentar o líquido espermático, e as 
conchas de madrepérola, que criam a imagem masculina assertiva. $\mathrm{Na}$ verdade, essas trocas constituem uma "substituiçáo" da criatividade masculina por seu correlato feminino.

Toda aquisição legítima de uma mulher e - como todos os seres humanos nascem da criatividade feminina - toda aquisiçáo de uma pessoa ocorre necessariamente por meio desse tipo de troca. Consequentemente, todo Daribi possui pagebidi ("pessoas no fundamento") que têm direito a receber riquezas masculinas em troca de sua proteção ou afiliação. Os pagebidi incluem os irmãos e outros parentes próximos de uma mulher, bem como os parentes maternos próximos de um homem ou de uma jovem solteira. Deve-se "pagar por" todas as pessoas dessa forma, e todo ato de troca estabelece um contraste entre o masculino e o feminino.

Assim, toda troca na qual uma mulher ou criança é "adquirida" por um homem corresponde a um ato de diferenciação, uma separação da mulher de seus parentes ou da criança (e às vezes do adolescente) de seus parentes maternos, realizada por meio da concessão de riquezas masculinas. E assim como todos têm pagebidi, que devem ser recompensados dessa

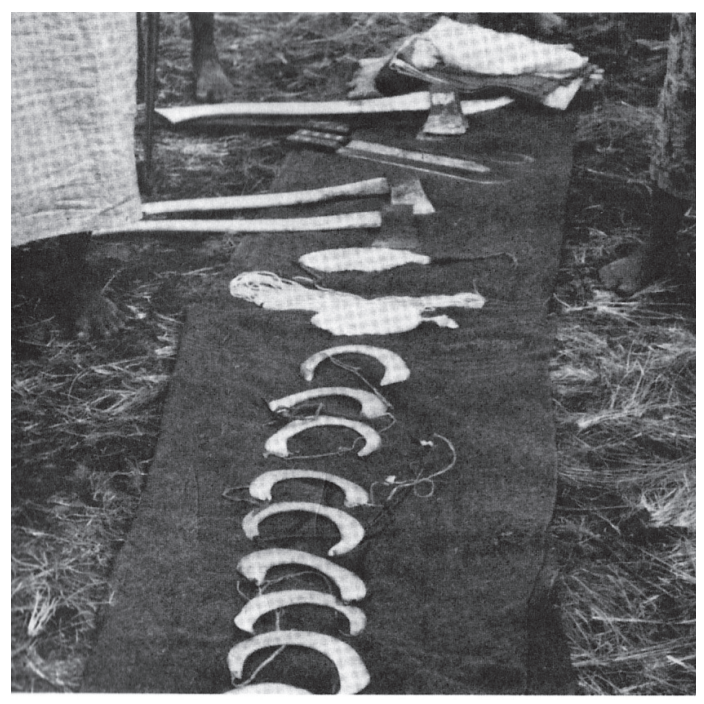

Fig 1 - Preço da noiva daribi: conchas de madrepérola, machados, facões, adereços de conchas e tecidos. (Masi, 1968) forma, todos também têm be bidi ("pessoas de casa”), principalmente o marido ou os parentes paternos, que realizam a compensação. Essa distinção, somada à troca diferenciante por meio da qual é realizada, é em si a questão mais importante da vida social daribi. Num sentido importante, ela é a vida social daribi, pois suas consequências e implicaçóes são respeitadas a despeito de outros fatores e circunstâncias. Os be’ bidi têm sempre de ser mantidos distintos dos pagebidi, de modo que mesmo se pessoas intimamente relacionadas decidissem se casar (como às vezes decidem), seus parentes - mesmo que todos vivam na mesma casa (como às vezes vivem) - teriam de se subdividir nessas duas categorias para a ocasião. Ademais, nesse ou em qualquer outro caso, os bé bidi são terminantemente proibidos de partilhar qualquer porção da carne dada aos outros pelos pagebidi.

Os próprios Daribi dizem que se casam com as irmãs e filhas daqueles para os quais "dão" carne, e não podem se casar entre aqueles com os quais "comem" (ou "compartilham") carne. Assim, a distinção explícita que se estabelece em qualquer troca é entre os que compartilham carne ou outras riquezas e os que trocam carne

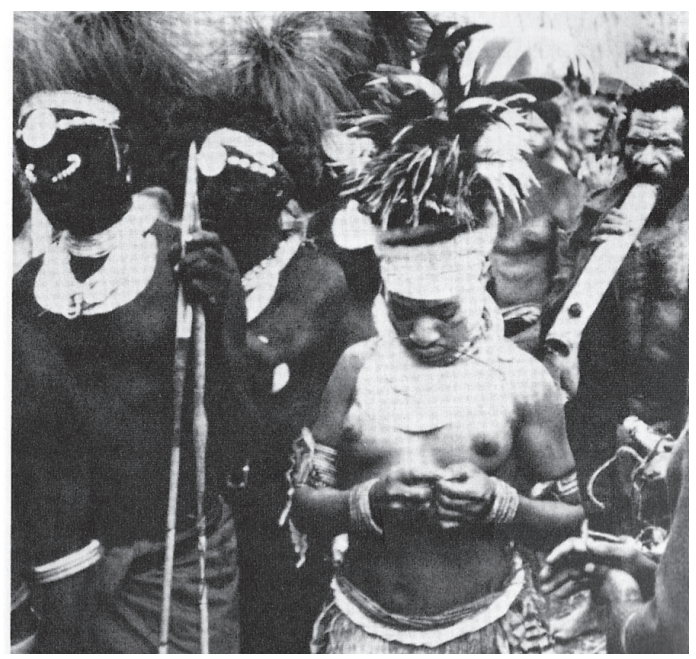

Fig 2 - Noiva daribi em pé ao lado de membros do "grupo do noivo", em trajes tradicionais: penas de casuar, conchas brancas, corpo e rosto enegrecidos com fuligem. (Masi, 1968) 
ou riquezas. Cada ato ou distinção desse tipo estabelece uma fronteira. Mas como o foco se volta para a própria distinção, essa fronteira é, na verdade, mais significativa do que as coisas que ela diferencia. Pode acontecer, por exemplo, de algumas pessoas que anteriormente se identificavam umas com as outras desejarem casar entre si; isso será tolerado, embora possa não ser coerente com as relaçôes anteriores, desde que uma diferenciação adequada e bem definida seja estabelecida entre elas.

Assim como no caso dos nomes, o conteúdo específico (definitivo ou descritivo) das coisas referidas (as "unidades" sociais, as categorias be bidi e pagebidi) permanece implícito: o que se explicita é a distinção que as separa ou diferencia. Portanto, assim como se pode dizer que os nomes "eliciam" coletividades sociais no ato de distingui-las, pode-se considerar que as trocas que atribuem direitos sobre uma mulher ou criança eliciam casos específicos de be bidi e pagebidi. Em virtude das restriçôes que necessariamente acompanham trocas desse tipo, toda troca criará, assim, suas próprias circunstâncias sociais. Mesmo que não se "parta" dos grupos, uma vez que estes nunca são deliberadamente organizados, mas tão-somente eliciados por meio do uso de nomes, o resultado final são sempre punhados específicos de pessoas como be' bidi e pagebidi. Trata-se de uma "sociedade automática”, que de repente se manifesta de forma concreta onde quer que as distinçóes corretas sejam feitas. $\mathrm{O}$ que podemos desejar chamar de socialidade "permanente" existe como um contexto associativo que emana de uma ocasiáo ad hoc desse tipo para outra.

Com exceção das restriçóes correntes relativas à partilha ou não das contínuas dádivas de carne que se seguem ao casamento e ao nascimento das crianças, os quais tendem a "congelar" as distinçôes e categorias, os agrupamentos não são mais completamente coerentes entre si do que aqueles eliciados pela nomeação. Com base na sobreposição de restriçóes ao compartilhamento, nodos de pessoas surgem em vários graus de inclusividade informal que denominei zibi, clã e comunidade (Wagner, 1967). (Como se acredita que os fluidos reprodutivos masculinos são aumentados e se acumulam pelo consumo de carne, um pai e seus filhos são automaticamente "compartilhadores de carne".) Contudo, isso não estabelece, de modo algum, uma hierarquia rígida, uma organizaçáo para a partilha e troca adequada de carne. Um clá é composto por zibi constitutivos, que tendem todos a cooperar na partilha e falar de sua associação mútua dessa forma, mas não é incomum que seus membros se casem entre si e, portanto, "troquem". Uma comunidade é composta por clâs que, na maioria das vezes, casaram, e portanto trocaram, entre si; contudo, eles se referem a sua associação como "partilha de carne". A coerência nem sempre é mantida de um "nível" nodal para outro; portanto, qualquer tentativa de compor o todo como um "sistema" ou "ordem” estará invariavelmente comprometida.

Assim, zibi, clã e comunidade não são grupos no sentido de construçóes deliberadamente organizadas ou ideologicamente regulamentadas. Termos como "clâ" e "comunidade" podem ser formas úteis de se referir a esses agrupamentos associativos, contanto que tenhamos em mente que esses termos geralmente denotam associaçóes bastante "não intencionais" e não tentemos transformá-los em representaçóes de nossas próprias corporaçóes e organismos conscientemente sócio-políticos. Eles são a socialidade e a relação humana sem distinçôes inerentes, e é por isso que as pessoas precisam elas mesmas estabelecer distinçóes, embora, é claro, também eliciem a socialidade no ato de estabelecê-las. Nesse aspecto, são o oposto de nossas formas ocidentais, em que as pessoas formam grupos por meio da participação deliberada e, assim, eliciam distinçôes de "classe" e "nacionalidade". 
250 | ROY WAGNER

Nas sociedades tribais, é um tanto quanto sem sentido perguntar-se onde estão os grupos em si, pois eles nunca se materializam de fato. O que vemos na forma de uma aldeia ou agrupamento comunal é apenas uma aproximação bastante semelhante, uma representação $a d$ hoc de uma abstração, que "dará conta" da situação. A socialidade é algo que "se torna", não que "se tornou", e sua eliciação se assemelha ao conceito de "deficit spending": as pessoas traçam fronteiras, impelem e eliciam, e as relaçóes tomam conta de si mesmas.

\section{Efeitos do contato com o Ocidente}

Quando os homens brancos chegaram a Karimui pela primeira vez, sentiram-se fortemente impelidos a descobrir grupos. Eles eram administradores que se deparavam com a tarefa de construir uma interface entre as "instituiçōes" dos nativos e as suas próprias com o propósito de decompor uma coleção de nomes e povoados distribuindo-os em grupos que pudessem servir como os elementos finais (locais) de uma cadeia política de comando. Eles eram herdeiros de uma tradição "colonial" autoconsciente, e muitos deles haviam frequentado cursos de "ciência dos grupos de descendência" como parte de seu treinamento. Em suma, sabiam qual supostamente deveria ser a configuraçáo da sociedade nativa. E eles também recebiam instruçóes explícitas sobre como lidar com os grupos: em cada (dito) grupo local, um líder, ou Tultul, era designado, e cada Tultul era encarregado de manter o "livro da aldeia", no qual se registravam os dados do censo. Ao se depararem com um desnorteante caos de terras de família dispersas e nomes sobrepostos, reagiam da única forma que sabiam - criavam grupos.

Para tanto, eles podem ter solicitado a ajuda das próprias pessoas, agrupando todas as que eram identificadas pelo mesmo nome (se não fossem muitas) e ignorando quaisquer contradiçôes com as quais não conseguissem lidar, pois se contentavam em deixar que as fronteiras do grupo tomassem conta de si mesmas. Em todo caso, as pessoas, que até então viviam em casas comunais de um ou dois andares (que abrigavam de duas a sessenta pessoas) dispersas entre os locais alternantes de seus roçados, eram obrigadas a abandonar o padrão tradicional e instalar-se em aldeias nucleadas. (Esse conceito era completamente novo para os Daribi, que ainda usam a palavra be, "casa", para se referirem a esses complexos.) Uma reorganizaçâo em aldeias desse tipo é característica da política e do controle administrativo em toda a Papua-Nova Guiné. Várias motivaçóes para isso já foram apontadas: diz-se que facilita a organização das pessoas para o censo, por exemplo, e que é mais salubre do que os arranjos aborígines. Mas na verdade ele apresenta uma vantagem predominante, que põe fim à ambiguidade mais relevante do ponto de vista desses outsiders: torna os "grupos" visíveis para pessoas

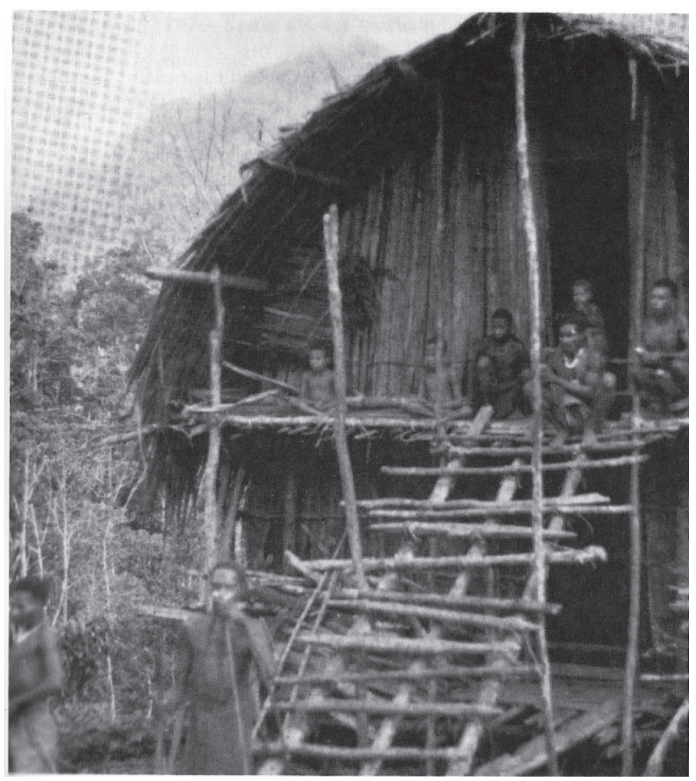

Fig 3 - Be'bidi: Povo twa em sua sigibe', casa comunal de dois andares (1963). Os homens vivem no andar superior e as mulheres, no inferior. 
que simplesmente não conseguem conceber a socialidade humana de nenhuma outra forma.

A maior parte das aldeias em Karimui foi formada em 1961-1962 (Russell et al., 1971, p. 83), embora alguns desgarrados ainda vivessem de acordo com o padrão tradicional até 1969. No final de 1963, quando cheguei pela primeira vez a Karimui, as aldeias eram parte característica da paisagem local; os nativos de fato viviam nesses núcleos, a despeito de quem os tivesse feito. Mas seria este um motivo suficiente para considerá-los grupos? A resposta a esta questão não é fácil, e uma boa resposta requer que apreciemos as evidências. Consideremos de perto o reassentamento do povo Weriai de Buruhwą.

Os oficiais de patrulha que encontraram os Weriai em meados da década de 1950 provavelmente ficaram desnorteados com a dispersão dessas pessoas. De modo a endireitar as coisas - e acidentalmente aumentar o potencial de mão de obra local - solicitaram que todos os Weriai mudassem para Baianabo. (A medida não foi tão extrema quanto pode parecer; os Kurube alegaram que estavam "se dirigindo lentamente" para Baianabo de qualquer modo, e esse tipo de "movimento em câmera lenta" era, de fato, bastante característico desses movimentos demográficos.) Por volta de 1960, todos os Weriai de Waramaru, bem como vá-

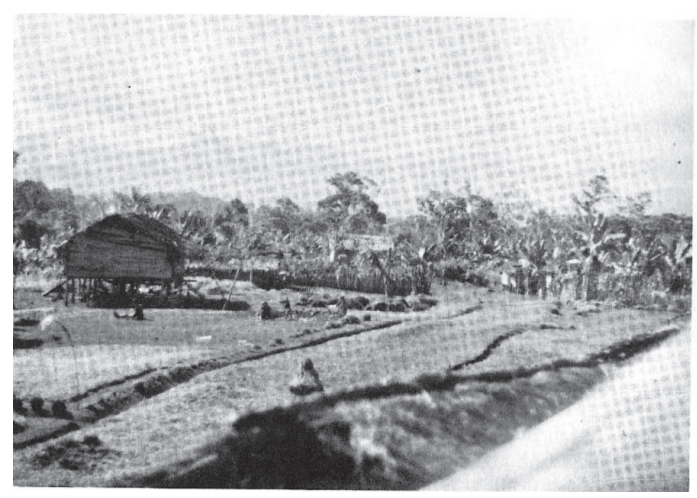

Fig 4 - Vista de Kurube (povoado C) em 1964. Embora as "casas enfileiradas" estejam se deteriorando, a grama foi cortada e a estrada escavada para esperar a visita do Oficial de Patrulha. rios dos que haviam se assentado recentemente em um local chamado Suguai, haviam se unido ao povo de Buruhwą em uma única casa comunal de dois andares em Baianabo. Vários outros Weriai de Nekapo haviam se mudado para casas semelhantes numa extensão de terra adjacente chamada Sonianedu.

Pouco tempo depois, os Weriai foram instados pelo governo (fortemente premidos por uma missão fundamentalista) a construir fileiras de moradias para famílias nucleares em estilo ocidental, ou "casas enfileiradas". Estas foram abandonadas em 1966 porque traziam aborrecimentos e colocavam a saúde em risco, mas as pessoas nunca voltaram à ocupação altamente concentrada em casas comunais que predominava antes do contato com o Ocidente. Assim, a "aldeia", tal como surgiu em 1968, assumiu a forma de uma fileira esforçada de casas, com "núcleos" de concentração perceptíveis, dispersas por quase um quilômetro ao longo de um caminho desimpedido conhecido localmente como a "estrada do grande carro do governo" (Fig. 4.5). Os nós ou povoados (designados de A a D na Fig. 4.5) provavelmente representam pessoas que compartilhariam a mesma casa comunal em condiçóes pré-contato.

As próprias pessoas não possuem termos gerais para esses povoados. Embora possam se referir a eles como be', essa palavra é mais frequentemente usada em conexáo com as casas propriamente ditas e seu uso é, portanto, ambíguo. Ademais, embora as pessoas com frequência se refiram ao povoado A como $b e$ ' Kilibali, a B como be' Noruai e a C ou D (ou a ambos) como be' Kurube, qualquer um desses nomes pode ser usado em referência à aldeia ou ao complexo como um todo. Por vezes o termo Weriai é aplicado a todo o complexo, mas isso raramente ocorre no interior da própria aldeia. É mais comum que não se faça referência alguma ao complexo como um todo. Em seu interior, termos como Kilibali, Noruai e Kurube 
252 Roy WAGNER
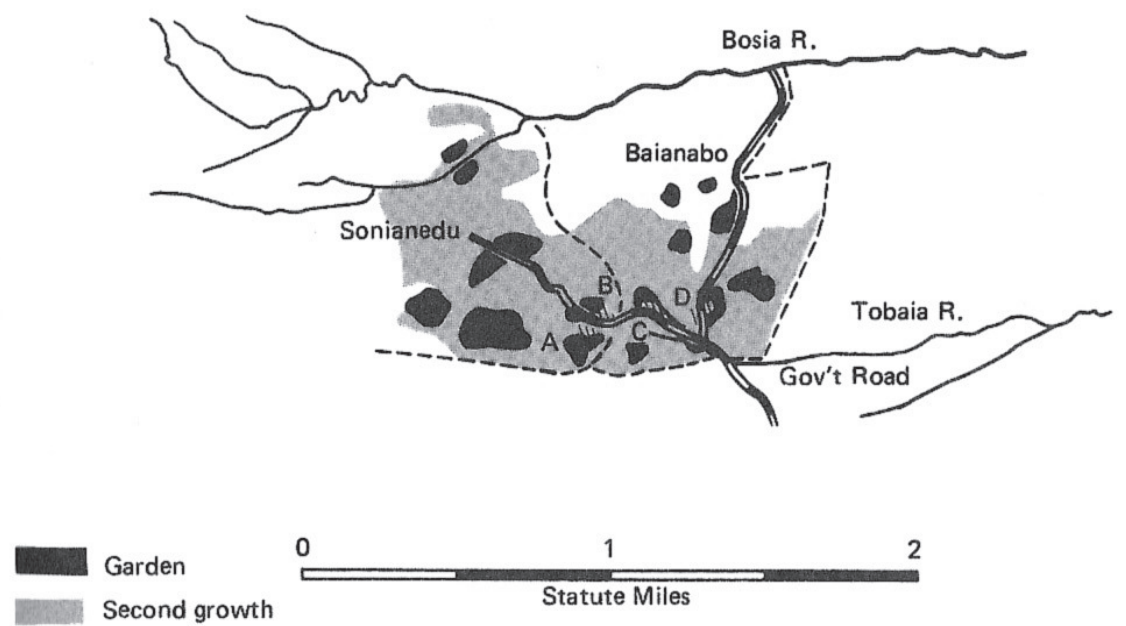

Fig 5 - Região de Baianabo-Sonianedu, 1968.

Tradução, da esquerda para a direita, de baixo para cima: roçado; floresta secundária; milhas terrestres; estrada do governo; Estrada Tobaia; Estrada Bosia.

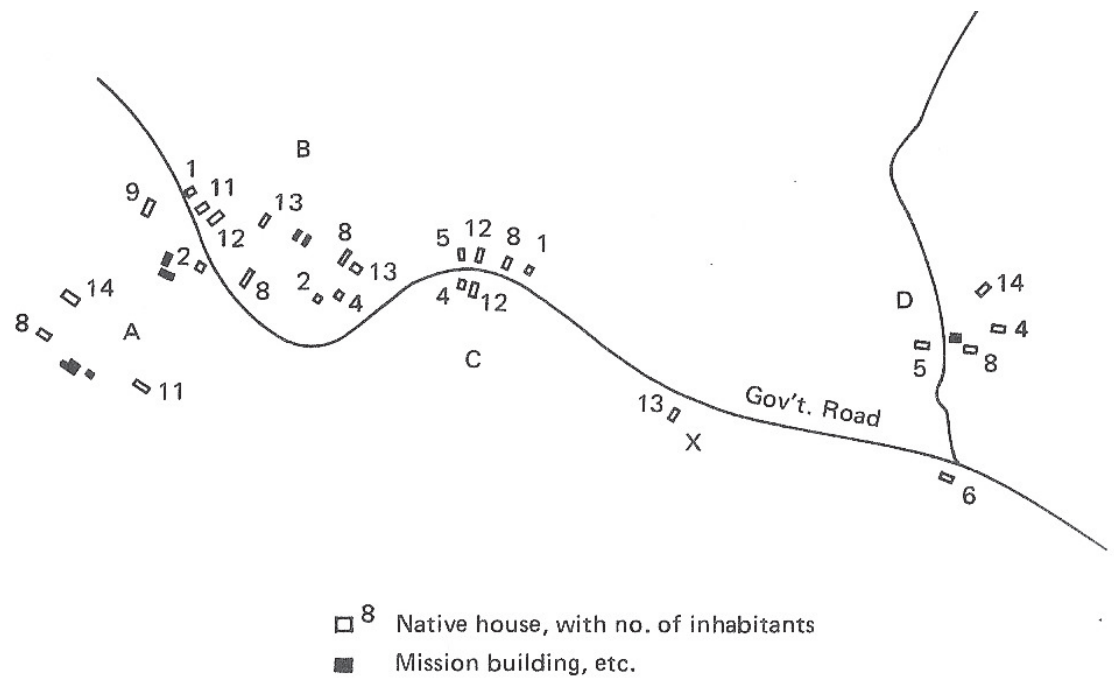

Fig 6 - Casas e povoados em Baianabo-Sonianedu, 1968.

Tradução, da esquerda para a direita, de baixo para cima: edifício da missão, etc.; casa nativa, com nº de habitantes; estrada do governo.

podem ser usados para traçar distinçóes, embora eles caracteristicamente não deem conta do fluxo reduzido, mas perceptível, de pessoas que transitam de um povoado a outro. De fato, os povoados $\mathrm{C}$ e $\mathrm{D}$, formados pela divisão de um povoado maior a partir de 1966, ainda não encontraram meios verbais efetivos para se diferenciar: os membros de cada um deles chamam seu próprio povoado de "Kurube" e improvisam um nome para o outro na hora

Uma vista de olhos sobre a real distribuição das casas (Fig. 6) mostra que os próprios nodos não são muito definidos. Em primeiro lugar, várias pessoas que, de outro modo, poderiam viver 
em A e B passam a maior parte de seu tempo em casas menores localizadas em seus roçados. Mas, mesmo no mapa, verifica-se a curiosa anomalia da casa marcada com um "X". Ela parece estar situada exatamente no meio, entre C e D. Existe um bom motivo para isso. Dos dois homens que moram nela com suas famílias, um tem uma relação próxima com as pessoas de $\mathrm{D}$, mas obteve sua mulher roubando-a do homem mais poderoso de D. Se falarmos em "grupos" definidos, fica difícil decidir qual afiliação atribuir a essas pessoas, mas felizmente, para eles ao menos, o problema nunca se coloca.

Esses povoados "aculturados" não são grupos mais literal e deliberadamente constituídos do que os povoados mais dispersos que existiam antes do controle do governo. Eles se misturam como uma socialidade contínua que parece clamar pelas distinçôes que efetivamente a eliciam. Trata-se de uma socialidade adaptada à maneira como os nativos lidam com ela (que é, de fato, uma forma de criá-la), a qual surgirá em qualquer lugar ou momento em que as pessoas escolherem lidar com ela assim. Se essa forma particular de socialidade parece de alguma forma adaptada à noção de sociedade do homem branco, isso ocorre apenas porque as pessoas elas mesmas foram fortemente coagidas a causar essa impressão. Elas também têm o hábito de vestir roupas de estilo ocidental, o que começou em parte porque outsiders desejavam que se vestissem como ocidentais. Isso não quer dizer, contudo, que elas usem suas roupas da forma como os ocidentais o fazem, que as tratem como os ocidentais as tratam, ou que pensem sobre elas como eles pensam.

Entretanto, se considerarmos as pessoas de uma certa forma, ignorando ou não enxergando as diferenças significativas, elas parecerão ocidentais. Analogamente, se considerarmos sua vida social de uma certa forma, veremos essas “aldeias", grupos, corporaçóes ou sistemas jurais. Não obstante, porque a socialidade nativa não resulta de "agrupamento", mas é antes produto de eliciação indireta, ela assume uma aparência distinta a cada mudança de perspectiva do observador. Examinamos o traçado real das casas concretas e descobrimos que ele é apenas vagamente representativo do "agrupamento". Se escolhermos diferenciar os povoados com base nas distinções nativas usuais (Tabela 1), descobrimos que cerca de $80 \%$ dos residentes podem ser atribuídos à be Weriai - cerca de 40\% para Noruai e $40 \%$ para Kurube (sem considerar o fato de que os últimos na verdade compreendem dois nodos, ou be). Mas se, ao invés disso, realizamos uma investigaçáo $\mathrm{da}$ ancestralidade paterna dos chefes masculinos das unidades residenciais (lembrando que eles são "automaticamente" partilhadores de carne com seus descendentes e, portanto, com seus próprios pais), encontramos uma situação bastante distinta (Tabela 4.2). Nesse aspecto, apenas cerca de metade das pessoas são be bidi Weriai, e Noruai e Kurube perfazem, cada um, cerca de $25 \%$ do total, ao passo que a maior parte do restante não é nem mesmo identificada como Para.

Tabela 1 - Identidades coletivas em Baianabo-Sonianedu (1968) com base no local de residência

\begin{tabular}{|l|l|l|}
\hline $\begin{array}{l}\text { Termos de } \\
\text { referência }\end{array}$ & $\begin{array}{l}\text { Número de } \\
\text { pessoas }\end{array}$ & $\begin{array}{l}\text { Porcentagem } \\
\text { do total }\end{array}$ \\
\hline Kilibali & & \\
\hline povoado A & 33 & 14,1 \\
\hline em casas no roçado & 13 & 5,6 \\
\hline Total & 46 & 19,7 \\
\hline Weriai & & \\
\hline Noruai & & \\
\hline povoado B & 83 & 35,4 \\
\hline em casas no roçado & 13 & 5,6 \\
\hline Total & 96 & 41,0 \\
\hline Kurube & & \\
\hline povoado C & 42 & 17,8 \\
\hline povoado D & 37 & 15,8 \\
\hline casa X & 13 & 5,6 \\
\hline Total & 92 & 39,2 \\
\hline Total & 188 & 80,2 \\
\hline Total geral & 234 & 99,9 \\
\hline & & \\
\hline
\end{tabular}


254 | Roy WAGNER

Tabela 2 - Identidades coletivas em Baianabo-Sonianedu (1968) com base na identificação genealógica do chefe masculino da unidade residencial

\begin{tabular}{|l|l|l|}
\hline Termos de referência & $\begin{array}{l}\text { Número de } \\
\text { pessoas }\end{array}$ & $\begin{array}{l}\text { Porcentagem do } \\
\text { total }\end{array}$ \\
\hline Para & & \\
\hline Weriai & & \\
\hline Kurube & 60 & 25,7 \\
\hline Noruai & 59 & 25,2 \\
\hline Total & 119 & 50,9 \\
\hline Yao & 4 & 1,7 \\
\hline Total & 123 & 52,6 \\
\hline Nekapo & & \\
\hline Kilibali & 67 & 28,6 \\
\hline Noru & & \\
\hline Dogwaro-Hagani & 28 & 11,9 \\
\hline Sogo & 10 & 4,3 \\
\hline Total & 38 & 16,2 \\
\hline Masi & & \\
\hline Yasa Masi & 3 & 1,3 \\
\hline Maina & 3 & 1,3 \\
\hline Total & 6 & 2,6 \\
\hline Total geral & 234 & 100,0 \\
\hline
\end{tabular}

Essas discrepâncias são o resultado direto de uma abordagem ingênua e literal de fenômenos que são indiretamente eliciados por seus criadores. Embora documentados de forma precisa, eles estão sujeitos a um certo equívoco de enfoque - respostas corretas para o problema errado. Se levados à atenção de um nativo, certamente não o inquietariam muito. Ainda que a residência e o compartilhamento da carne com os bé bidi de alguém sejam questôes de importância crucial para os Daribi, não são utilizadas como programa para a formaçáo deliberada de grupos - não fazem parte de um esforço sistemático para construir uma sociedade e não apresentarão os tipos de coerência que esperamos ao supor isso.

Discrepâncias desse tipo aparecem reiteradas vezes na literatura antropológica sobre as terras altas da Nova Guiné e, como a maior parte dos estudiosos da área compartilhava uma fé na necessidade dos grupos, as discrepâncias são frequentemente apresentadas como evidências de um problema importante. Como os habitantes das terras altas não parecem prestar muita atenção aos supostos "dogmas da descendência”, diz-se que são pragmatistas, ou se supóe que os dogmas "reais" são os da residência (de Lepervanche, 1967). Contudo, parece que foram os antropólogos, e não os nativos (a julgar pelos registros estatísticos), que trouxeram os dogmas à tona. A alternativa à abordagem do "dogma" foi a suposição da "estrutura frouxa", grupos com certa "margem" estratégica ou flexível em suas organizaçóes (Pouwer, 1960) - em resumo, um outro arranjo para possuir seus grupos teoricamente e comê-los pragmaticamente ${ }^{9}$. Outros foram mais longe e sugeriram que a ação dos melanésios tem um fundamento de improvisação (Held, 1961; Wagner, 1972), ou postularam uma concepção da própria sociedade como fluxo (Watson, 1970), como fiz aqui.

É claro que se administradores capazes e experientes, munidos de um mandado das Naçôes Unidas e fuzis de $7,7 \mathrm{~mm}$, não foram capazes de reorganizar essas pessoas em grupos claramente delimitados ao modo ocidental, estaríamos pedindo demais aos acadêmicos ao esperar que eles o façam com caneta, tinta e definiçóes. O problema está mal colocado se imaginamos o "agrupamento" (ou seja, a construção deliberada da sociedade) como tarefa do nativo quando ela é, na verdade, nossa própria tarefa. É nosso trabalho, e não do nativo, dar conta das discrepâncias, uma vez que não se trata de discrepâncias para ele. É também nosso trabalho explicar por que elas deveriam ser consideradas como discrepantes, ou como irrelevantes, pois ao determinar quais serão nossas suposiçóes e problemas iniciais, também determinamos que tipos de evidências seráo relevantes e admissíveis. 
EXISTEM Grupos SOCIAIS NAS TERRAS ALTAS DA Nova GuINÉ? | 255

\section{Conclusão}

Para muitas pessoas, é bem mais fácil supor a existência de grupos do que tentar compreender as sutilezas de como os nativos conceitualizam sua socialidade. Os "grupos" e a "sociedade" formam uma espécie de idioma taquigráfico moderno para certos fenômenos sociais - eles existem como parte do "objeto de estudo", como "fatos", para quem acredita neles ou precisa deles. Entretanto, a questão de se esses fatos existem onde quer que tenham sido postulados, se "o social" existe ao nível objetivo dos fenômenos, é uma questão de qual teoria decidimos seguir. Estamos habituados a confundir as formas como estudamos os fenômenos, as teorias por meio das quais os entendemos, com os próprios fenômenos. Assim, falamos sobre a "química do corpo", "a biologia da reprodução humana", "a ecologia de uma floresta", falamos sobre o mundo segundo os modos como viemos a conhecê-lo (o que é bem compreensível).

Os modelos são modos de fazer (ou, como a linguagem da ciência preferiria, de "descobrir") os vários "níveis" fenomênicos ao criar as características segundo as quais os percebemos - a ciência dos grupos de descendência é um conjunto de modelos para transformar a interação social em grupos de descendência. $\mathrm{O}$ analista pode ter certas predisposiçóes a respeito de como gostaria de elaborar, dessa forma, o mundo de sua investigação, ou pode desejar tentar trabalhar em vários "níveis", mas uma vez que se tenha comprometido com um certo modelo, suas conclusões estão em certa medida predeterminadas.

A questão dos grupos sociais e sua "realidade" pode ou não ser significativa, dependendo do tipo de antropologia em que se está interessado. Mas as implicaçóes do que o antropólogo faz quando supóe a existência e a necessidade dos grupos são questôes essenciais a serem consideradas por todos os antropólogos. Elas sugerem que nós somos tão criadores quanto os povos que estudamos, e precisamos prestar atençáo tanto à nossa criatividade quanto à criatividade deles. Dito de modo um pouco diferente, a suposição da criatividade coloca o antropólogo em igualdade de condiçóes com seus sujeitos de pesquisa; também o nativo é um "antropólogo", com sua própria "hipótese de pesquisa" sobre seu modo de vida. E a despeito de como desejamos compor esse modo de vida, temos de avir-nos com a "teoria" do próprio nativo por uma questão de dever profissional e ético.

Esse tipo de ciência, que lida com um sujeito de pesquisa pertencente à mesma ordem de existência fenomênica que suas próprias hipóteses e conclusóes, é comparativamente tardia. Quando finalmente surgiu, todas as disciplinas mais bem estabelecidas já haviam desenvolvido uma noção de "ciência" fundamentada na natureza "determinada" de seu objeto. A ideia da natureza como sistema mecanicista (ou comportamental) de constituiçāo precisa, determinada e uniforme tornou possível conceber uma "ciência exata" cuja tarefa era conhecer ou prever essa ordem. Isso forneceu aos cientistas um ideal de certeza absoluta que permaneceu praticamente inabalado pela "teoria da relatividade" de Einstein ou pelo princípio da incerteza de Heisenberg, pois náo obstante o quão indeterminada a natureza possa ser, em última instância, sua incerteza e relatividade puderam ser medidas com exatidáo e transformadas em um princípio. Considerar (acreditar, provar, verificar) que o modelo é idêntico (ou quase isso) ao objeto de estudo equivale ao "estilo" de fazer a realidade fenomênica sob a impressão de que ela está sendo descoberta ou prevista.

Mas uma antropologia que se comprometa a considerar toda operaçáo cultural (seja ação ou experiência, seja a sua própria ou a de seus sujeitos de pesquisa) como um ato de criatividade não pode se dar ao luxo de atribuir va- 
lor de "realidade" a qualquer uma delas. Pois é precisamente essa decisão que impede que as operaçóes culturais sejam consideradas atos relativos e criativos. Se o antropólogo está sujeito a falhas, o nativo não pode ser infalível; se o nativo pode falhar, então a antropologia de fato tem pouco a ganhar com a adoção de uma ideologia determinista.

\section{Leituras escolhidas}

GLASSE, M. e MEGGITT, M. J. (eds.). Pigs, Pearlshells, and Women: Marriage in the New Guinea Highlands. Englewood Cliffs, N. J.: Prentice-Hall, 1969.

Coletânea com onze artigos curtos sobre o casamento em várias sociedades das terras altas, com introdução de Mervyn Meggitt. A obra convida a comparações teóricas e etnográficas entre os diferentes pontos de vista e sociedades representados.

LEACH, E. R. Repensando a antropologia. São Paulo: Editora Perspectiva, 2001.

Esta coletânea de ensaios provocadores pode parecer difícil para o iniciante, mas é uma excelente maneira de experimentar em primeira mão o impacto que Leach e seus colegas estruturalistas tiveram sobre o mundo da antropologia social britânica. Começando com uma introduçáo geral de grande utilidade, Leach se estende consideravelmente, discutindo sua interpretação estrutural de alguns problemas funcionalistas clássicos, e conclui com uma incursão pela antropologia simbólica.

LÉVI-STRAUSS, C. Antropologia estrutural. São Paulo: Cosac \& Naify, 2008.

Coletânea de artigos sobre uma ampla gama de assuntos, subdividida em seçóes que correspondem a Linguagem e Parentesco, Estrutura Social, Magia e Religião, Arte e Problemas de Método e Ensino. A obra apresenta Lévi-Strauss em sua faceta mais acessível e compreensível, e seus ensaios investem grande esforço em explicar alguns dos mais difíceis aspectos e implicaçóes de seu modo de teorização. Um leitor interessado pode desejar complementar este livro com Claude Lévi-Strauss, de Edmund Leach, Nova York: Viking Press, 1970, Modern Masters Series, tentativa mais ambiciosa de apresentar a linha de argumento teórico de Lévi-Strauss de forma mais sistemática (embora com frequência fortemente enviesada).
MAUSS, Marcel. Ensaio sobre a dádiva. In: Sociologia e antropologia. São Paulo: Cosac \& Naify, 2005.

Clássico da antropologia que exerceu profunda influência sobre o pensamento moderno, esta obra é extremamente legível e abunda em exemplos etnográficos. O leitor pode desejar complementar este livro com um tratamento mais moderno do tema: On the Sociology of Primitive Exchange, de Marshall D. Sahlins. In: ASA Monograph No. 1: The Relevance of Models for Social Anthropology, M. Banton (ed.). Nova York: Frederick A. Praeger, 1965.

RADCLIFFE-BROWN, A. R. Estrutura e função na sociedade primitiva. Petrópolis: Editora Vozes, 1973.

Este clássico da antropologia social reúne várias das abordagens de seu autor, que teve papel proeminente no desenvolvimento de uma "ciência" funcional "dos grupos de descendência”. Muito do que está implícito em outros escritos dos antropólogos sociais britânicos remonta aos ensaios contidos nesse volume.

SCHNEIDER, David M. "Some Muddles in the Models: Or, How the System Really Works" in ASA Monograph No. 1: The Relevance of Models for Social Anthropology, M. Banton (ed.). Nova York: Frederick A. Praeger, 1965.

Uma análise e esclarecimento de dois corpora teóricos predominantes na antropologia social - a "teoria da descendência" e a "teoria da aliança" -, com particular atenção às diferenças conceituais cruciais que os dividem. Embora bastante sofisticada, a exposição é clara e vigorosa o suficiente para recompensar uma leitura atenta e cuidadosa com alguns verdadeiros insights sobre uma crise teórica significativa.

\section{Notas}

1. Agradeço a Suely Kofes por algumas sugestóes muito pertinentes à traduçáo deste texto.

2. Na tradução de Estrutura e função na sociedade primitiva, optou-se por traduzir joking como "brincadeira”. Na presente tradução decidiu-se traduzir o termo como "jocosidade", julgado mais adequado. Assim, o termo foi substituído na citação, que no mais foi transcrita da tradução do livro de Radcliffe-Brown para o português. (N.T.)

3. Em inglês no original, betwixt and between.

4. Em inglês, pawn, que além de "peão" poderia ser traduzido como "penhor", "garantia". (N.T.) 
EXISTEM GRUPOS SOCIAIS NAS TERRAS ALTAS DA Nova GUINÉ? $\mid 257$

5. Os termos daribi aqui citados foram escritos na ortografia latina padrão, na qual cada vogal tem seu próprio som distintivo (por exemplo, o $e$ é pronunciado como o a em "gate", o $u$ como o oo em "boot") e o $r$ é levemente vibrante. As palavras são, em geral, pronunciadas como o seriam em espanhol. $\mathrm{O}$ apóstrofo (como em mama) indica tom alto, e o cedilha (como em Buruhwą) denota nasalizaçáo.

6. Optamos por manter aqui o termo como existe em português, embora o termo "elicitar", neologismo criado a partir do inglês to elicit, seja usado em algumas disciplinas e tenha sido adotado na tradução recentemente publicada d' $A$ invenção da cultura. (N.T.)

7. É pouco surpreendente, à luz disso, que Leach e outros tenham introduzido o conceito de tempo "social" ou "genealógico" como dispositivo explicativo. Mesmo as imagens escolhidas pelos melanésios - "linhas" em pidgin, "cordas" em muitos idiomas locais - enfatizam a continuidade, e não a grupidade descontínua.

8. Deficit orçamentário sistemático cujo objetivo é estimular a atividade econômica. (N.T.)

9. O trecho faz referência a um provérbio em inglês sobre a impossibilidade de se ter tudo: You can't have the cake and eat it, too. - literalmente: "Não se pode ter o bolo e comê-lo ao mesmo tempo". (N.T.)

\section{Referências bibliográficas}

DE LEPERVANCHE, M. Descent, Residence, and Leadership in the New Guinea Highlands. Oceania, v. 38, n. 2, p. 134-158, 1967.

DOUGLAS, Mary. Pureza e perigo. Lisboa: Ediçóes 70, 1991.

HELD, G. J. De Papoea. Cultuurimprovisator. Gravenhage: Bandung: N. V. Uitgeverij W. van Hoeve, 1951.

RADCLIFFE-BROWN, A. R. Estrutura e função na sociedade primitiva. Petrópolis: Editora Vozes, 1973.

LÉVI-STRAUSS, Claude. Totemismo hoje. Petrópolis: Editora Vozes, 1975.

- As estruturas elementares do parentesco. Petrópolis: Editora Vozes, 2003.

POUWER, J. Loosely Structured Societies in Netherlands New Guinea. Bijdragen tot de taal-, land-, en Volkenkunde, 116, p. 109-118, 1960.

RUSSELL, D. A. et al. Blood Groups and Salivary ABH Secretion of Inhabitants of the Karimui Plateau and Adjoining Areas of the New Guinea Highlands. Human Biology in Oceania, I, 2, 1971.

WAGNER, Roy. The Curse of Souw: Principles of Daribi Clan Definition and Alliance in New Guinea. Chicago: University of Chicago Press, 1967.

- Habu: The Innovation of Meaning in Daribi Religion. Chicago: University of Chicago Press, 1972.

WATSON, J. B. Society as Organized Flow. Southwestern Journal of Anthropology, v. 26, n. 1, p. 107-124, 1970.

\title{
traduzido de
}

WAGNER, Roy. "Are There Social Groups in the New Guinea Highlands?" In: LEAF, Murray. Frontiers of Anthropology. Nova York: Cincinnati: Toronto: Londres: Melbourne: D. Van Nostrand Company. 1974. pp. 95-122.

\author{
tradutora Iracema Dulley \\ Doutoranda em Antropologia Social / USP
}

$\begin{array}{ll}\text { revisora } & \text { Olivia Janequine } \\ & \text { Mestre em Antropologia Social / Unicamp }\end{array}$

revisor Ariel Rolim

Mestrando em Antropologia Social / Unicamp

Recebida em 14/06/2010

Aceita para publicação em 14/06/2010

cadernos de campo, São Paulo, n. 19, p. 237-257, 2010 